\title{
Social Welfare and Catholic Social Teaching: Foundational Theological Principles for Case Studies
}

\author{
Thomas Massaro, S.J.
}

check for updates

Citation: Massaro, Thomas. 2021. Social Welfare and Catholic Social Teaching: Foundational Theological Principles for Case Studies. Religions 12: 288. https://doi.org/10.3390/ rel12050288

Academic Editors: Miguel Glatzer and Paul Christopher Manuel

Received: 12 March 2021

Accepted: 15 April 2021

Published: 21 April 2021

Publisher's Note: MDPI stays neutra with regard to jurisdictional claims in published maps and institutional affiliations.

Copyright: (C) 2021 by the author. Licensee MDPI, Basel, Switzerland. This article is an open access article distributed under the terms and conditions of the Creative Commons Attribution (CC BY) license (https:/ / creativecommons.org/licenses/by/ $4.0 /)$.
Department of Theology, Fordham University, Bronx, NY 10458, USA; tmassaro@fordham.edu

\begin{abstract}
For well over a century, Catholic social teaching has advocated for generous social welfare policies that assist members of poor and marginalized communities. Efforts to understand and describe the shape and influence of these advocacy endeavors, naturally conducted primarily by social scientists and historians of policy, must be grounded in foundational theological considerations, as well as an appreciation of recent church history. Among the topics of central relevance are the tensions within these teachings between: (1) engagement and intervention; (2) key contending metaphors, such as "blueprint" and "yardstick"; and (3) the interplay between universal principles and local applications. Only by first appreciating these tensions in their historical and theological dimensions may a fully adequate portrayal of the purpose and influence of Catholic social teaching emerge, even if a significant share of these tensions remains ultimately unresolved. Clarifying these key issues in the developing self-awareness of Catholic social teaching enhances our ability to chart a course forward regarding the prospect of fostering social change, even within highly challenging pluralistic contexts. Adhering to hard-won lessons from past social involvements will allow Catholicism to retain its constructive influence on future social welfare policy.
\end{abstract}

Keywords: Catholic social teaching; social welfare; church and state; Second Vatican Council

This essay seeks to provide foundational insights to ground the analysis of the several contributions to this Special Issue of the journal, which invites analysis of the role of Catholic social teaching in anti-poverty efforts in a variety of national and social contexts. Modern Catholic social teaching has indeed provided an impetus for the reform of economic structures, especially in ways that assist disadvantaged members of society. Although the energies unleashed by church teaching documents and hands-on activism under Catholic auspices display a mixed record of success and sometimes contradictory trajectories, beyond doubt is the enduring influence of these teachings on social justice. Careful studies of these vehicles of Catholic social teaching-both the documents that spell it out and the practitioners who translate words and doctrines into the realities of programs and institutions to assist the poor-make a great contribution to our understanding of the role of religion in inspiring social reform.

Many of those contributors will of course be social scientists-sociologists, political scientists, economists, cultural historians, policy analysts and others-who conduct rigorous investigations and offer well-documented insight into the role played by Catholic social teaching in various contexts throughout the world. What have been its successes and failures - and especially instances and trajectories of its greatest influence-within various countries and regions of the world? This is obviously a complex and fascinating topic, not only for Catholics but for any researcher interested in the influence of the Roman Catholic community-both in localities where it is in ascendancy as well as in places where it represents only a small minority voice. As a theologian, I venture merely to help set the table for these studies by framing the subsequent analysis in ways that are true to the theological heritage within which Catholic teachings on social justice are offered. What do church leaders (popes, councils and bishops) intend precisely to do when they promulgate official Catholic social teaching? How does the exercise of formal teaching authority (captured in the theological category magisterium) intersect with the world of 
secular realities, such as labor markets, public policies and social forces that determine the fate of our least advantaged members of society?

In short, this essay will provide specifically theological commentary regarding the significance, aspirations and limitations of Catholic social thought as it carves out its role in influencing public policies in the contemporary world. The objective here is to sketch the landscape upon which the Catholic Church's efforts to contribute to the attainment of social justice have played out, with an emphasis on the church's self-conscious pursuit of Gospel values that include effective care for the poor and provision for their needs. Toward this end, subsequent sections of this essay will offer a series of observations regarding the general trajectory of modern Catholic social teaching in the 130 years since Pope Leo XIII inaugurated this genre of church teaching by publishing his landmark statement on the demands of social justice in the rapidly industrializing economy of his era, the first social encyclical Rerum Novarum (Leo XIII [1891] 2010). We begin by examining three key tensions within these teachings and conclude with a brief description of the features of a "public theology" that maximizes the reach and influence of these teachings on social justice in a way that is fully constructive and socially responsible.

\section{Three Key Tensions in the Self-Awareness of Catholic Social Thought}

It is crucial to clarify from the outset, especially for those less familiar with church history and theology, that we are entering upon hotly contested terrain when we launch any study of "what the Catholic Church says or does regarding social justice" or "how Catholicism operates in society". Perceptions that the Roman Catholic Church functions as a monolithic institution with unwavering objectives and unified operationalization require significant correction. The more nuanced picture that will emerge from any study of the history of church involvements in the pursuit of social justice will reveal a great diversity of responses, both in thought and in action, from era to era and from place to place. While Catholicism features, in comparison to other world religions, a highly centralized authority structure and a marked continuity in institutional direction, it nevertheless exhibits substantial diversity in its response to events and challenges in the contexts where it finds itself.

While observers make sweeping generalizations at their own peril, certain sturdy categories do provide insight into such topics related to loci where the church meets the world, such as the project of Catholic social teaching and the church's public theology in general. This section traces the broad lines of three key tensions within the tradition, relying upon three paired categories: (1) engagement-intervention; (2) the analogies of blueprint and yardstick; and (3) universal principles and local applications. These precise expressions are ultimately my own personally preferred formulations, but the concepts they convey are far from idiosyncratic, even if hardly exhaustive in nature. While further categories might surely be germane to our purpose of appreciating the parameters within which these teachings operate, the treatment I offer below under these labels will shed light on the most significant tensions that underlie the purpose, extent and functioning of Catholic social teaching and the self-awareness of the Catholic Church as it turns to the needs of the world beyond its walls.

\section{Engagement or Intervention?}

While Max Weber (1946) did us a great service in introducing the categories of innerworldly and other-worldly to characterize the basic stances of any faith community vis à vis the world beyond its borders, ultimately, these ideal types fail to do much work in the contemporary world. On a practical level, adherents of any religion nowadays will interact with many people, institutions and forces beyond the ambit and control of that given religious community. The world is inescapably pluralistic these days; only in rare limit situations may religious communities and their members find it possible to avoid all forms of engagement in the wider society and its institutions. While the sectarian impulse to detach and withdraw from public life, or at least to keep a low profile and minimize the public-facing aspects of life in society, might remain, every religion will inevitably be 
challenged to develop at least a rudimentary version of "a social ethic" - some awareness of its place in relation to outsiders and social forces that it does not control, but with which it must relate.

How will a given faith community maintain a robust sense of its distinctive identity while simultaneously achieving a healthy understanding of its relationship to the wider society? How will it conduct its affairs in ways that accord due respect to the necessary functions of "boundary work"-including helping its members avoid the extremes of undue compartmentalization and utter conflation of duties to religious community and to political community? Whether we dub this function the church-world, religion-society, spiritual-temporal, faith-profane, or even, with a nod to the Christian worldview, the Kingdom-history or Christ-culture (Niebuhr 1951) dynamic, the engagement of organized religion with a public life that is pluralist and secular in tone appears unavoidable (Tracy 2020). The history of world religions demonstrates that this project of attending to such boundaries proceeds best when people of faith, confronted with the challenging conditions of modernity, are as reflective as possible about the stances they assume precisely as a worshiping community immersed in a broader secular society.

The basic church-world relationship is complicated in a distinctive way for Roman Catholicism because of its long history of functioning as the established religion of practically an entire continent (Europe) and many places beyond (due to missionary expansion, often closely associated with the colonial empires of Christianity's home base). While a variety of specific institutional arrangements were in place (both before but especially after the Protestant Reformation of the sixteenth century), the historical reality of Christendom presents a challenging legacy for any Christian church, but especially for Roman Catholicism. For an institution that for centuries dominated the political and social order of Western civilization, replete with throne-and-altar arrangements and the phenomenon of caesaropapism in its various faces, the emergence of a modern secular order, featuring newly sharpened institutional separations of church and state and an abruptly curtailed set of privileges for organized religion, presents quite a shock.

One way to narrate this story is to emphasize the progressive differentiation of secular and religious authority - a trope adopted by certain versions of the secularization hypothesis to describe the diminishing hold of religious institutions upon the operations of advanced societies (Bruce 2011). Regardless of the outcome of debates over the accuracy of such accounts, it is obvious that formerly established churches such as Roman Catholicism face a continuing struggle to renegotiate the previously settled relationships between church life and secular affairs, and subsequently to maintain a consistent stance that allows religious authorities to function in a coherent and constructive way, albeit with diminished sway. Of greatest relevance, then, to our investigation of the self-understanding of Roman Catholicism that undergirds this church's social teaching is the way this church has grappled with the reality that has come to be referred to as "the autonomy of the secular".

The arc of this theological inquiry stretches over many centuries. The longest version of this particular story would reach all the way back to the words of Jesus (for example, the admonition in John 18:36: "my kingdom is not of this world") and to Patristic era theologians such as Tertullian (with his famous metaphorical question, posed circa 200 A.D.: "What has Jerusalem to say to Athens?"). Moving ahead one millennium, a dramatic high point in the unfolding controversy over proper social ordering arrived in 1302 when Pope Boniface VIII promulgated the bull Unam Sanctam (Tierney 1988) declaring in no uncertain terms unrestricted papal supremacy (by no means limited to spiritual authority) over all secular rulers. While Boniface directed his claims primarily at a single opponent (King Philip the Fair of France), his successor (at a distance of another half millennium) Pope Pius IX had broader targets of reproach in mind when he appended his "Syllabus of Errors" to the 1864 encyclical Quanta Cura. Brushing aside even the most evident lessons of the intervening centuries of Renaissance, Reformation and early modernity, Pius struck a reactionary pose that condemned all challenges to supreme papal authority, and particularly those associated with the French Revolution that had so fiercely attacked the church 
75 years earlier. Memories die hard and grievances fester; nostalgia for long-defunct medieval arrangements dominated the Catholic imagination throughout what historian John W. O'Malley (2008, pp. 53-92) refers to as "the long nineteenth century" (consisting of the full span of years from 1789-1962) that in crucial ways persisted in the consciousness of Catholic leaders right up to the dawn of the Space Age.

The long-overdue reversal of these maximalist claims about rightful domination of church authority over secular matters came only with the convening of the Second Vatican Council (1962-1965). It was at this ecumenical council (the first in over 90 years) that the Roman Catholic Church at last officially renounced its previously held aspirations to a theocratic-style domination of society - a vestigial claim that became a casualty to the recognition of a universal right to religious liberty expressed in the "Declaration of Religious Freedom" (Dignitatis Humanae) ${ }^{1}$ passed nearly unanimously by the delegates on the final day of the Council (Abbott, S.J. 1966, pp. 675-96). On that same day, the Council Fathers approved the final draft of the social teaching document Gaudium et Spes, ${ }^{2}$ also known by the telling title "Pastoral Constitution on the Church in the Modern World" (Abbott, S.J. 1966, pp. 199-308). This elaborate and groundbreaking document contained a key paragraph (no. 36) with the heading "The Rightful Independence of Earthly Affairs".

Without explicitly repudiating past formulations (church documents, out of deference to inherited traditions, almost never call attention to the changes they signal, however momentous), the Council Fathers here broke new ground regarding the church's operative theology of the temporal world. Exactly 101 years after Pius IX issued his "Syllabus of Errors" pronouncing any such approach as anathema, Vatican II was calling for "habits of mind" that will recognize "and attend to the rightful independence of science" (where the term science, by Vatican convention, refers broadly to all branches of learning, not merely natural science narrowly conceived). The reader is wise not to allow the irenic-sounding language of this section of the document (n.b.: all cited phrases in this present paragraph are found in number 36 of Gaudium et Spes) to obscure the starkness of its claims. While it may sound anodyne to point out, as this paragraph does, that it "harmonizes with the will of the Creator" for "created things and societies to enjoy their own laws and values", there is hidden dynamite even in these smooth-sounding phrases.

While the specific implications of this shift in mentality for the church's involvement in social justice efforts may not be immediately evident, the attentive reader finds further clues about the Council Fathers' intentions to signal a bold new approach merely a halfdozen sections later in this document. Number 43 of Gaudium et Spes (the source of all quoted phrases in this present paragraph) reminds Christians that the "discharge of [their] moral obligations" includes attention to "temporal duties" and "earthly activities" besides "religious life" and "acts of worship alone". Next arises the question of precisely how ordinary Christians are to discern specific proper courses of action in these temporal enterprises. Without hesitation, the document endorses as the most reliable and readily available guide to the decision-making process of all people "the function of their wellformed Christian conscience", a human faculty that had already been treated (and effusively lauded) in number 16 of the document. While the inviolability of the human conscience had throughout Christian history served as a pivotal theological principle and ethical norm, the breakthrough here at Vatican II involves how this council document points away from clerical authorities as the sole (or even primary) sources of wisdom and guidance in decision making in freedom. Previous church teaching on conscience formation had reserved a privileged (indeed, almost exclusive) place for magisterial authority as a source of such guidance, as only officials of the church were at the time recognized as authentic and reliable interpreters of the natural law of God imbedded in creation. Yet, number 43 of this 1965 document continues: "Let the layman not imagine that his pastors are always such experts, that to every problem which arises, however complicated, they can readily give him a concrete solution or even that such is their mission". A clearer disavowal of previous claims of magisterial omnicompetence is hard to imagine. 
This exhortation constitutes not only an encouragement of the then-bourgeoning movement within the church toward lay empowerment, ${ }^{3}$ but also of the rightful autonomy of secular, earthly affairs as well as the role of the free conscience in discernment. The overall effect spells a transition to a new methodology with the greatest relevance for Catholic social teaching. Catholic theology was replacing its previous top-down and deductive style of theology with a more bottom-up and inductive approach-one featuring a marked new openness to emerging information and even a certain humility before the data gathered by the techniques of social analysis and the pastoral circle (the see-judge-act schema popularized by practitioners of Catholic social action in the decades preceding Vatican II). Indeed, one of the very opening paragraphs of Gaudium et Spes (no. 4) had already introduced this shift by inviting readers to consider "the duty of scrutinizing the signs of the times and interpreting them in the light of the Gospel". The then-existing four social encyclicals (with publication dates of 1891, 1931, 1961 and 1963), for all their commendable openness to new social and economic realities, had failed to adopt such an updated methodology, despite the growing influence of novel currents of liberal theology that had challenged the church to do just that throughout the very decades that witnessed the growth of official church social teaching. The social encyclicals of Leo XIII, Pius XI and John XXIII emphasize unchanging elements of social order and rely on a rather static natural law framework even as they apply often creative solutions to emerging economic and political realities.

For example, there is nothing inductive or bottom-up in style about Leo XIII's treatment of proper responses to social upheaval in a section of Rerum Novarum (no. 22) labeled "The Church Applies the Remedy". Leo's starting point and frame of reference is solidly ecclesiocentric, so the focus remains on what the church has to offer the outside world, into which it intervenes with measures of mercy and justice, in both words of advice and acts of benevolence. Yes, Leo's church sincerely intends to be generous, but it is a generosity fashioned according to terms of the church's own choosing, not a thoroughgoing embrace of the model of "church as servant to the world" (Dulles 1978). Nor do we find much of an inductive flavor in John XXIII's call for a stable political order in the section of Pacem in Terris (nos. 46-52) labeled "Necessity and Divine Origin of Authority", despite the fact that John had explicitly endorsed the see-judge-act method two years earlier in number 236 of his social encyclical Mater et Magistra. ${ }^{4}$

Thus, the teachings of these popes who pioneered the genre or Catholic social teaching, as progressive and forward-looking as they were in so many ways, exposed a limitation in the theology that they (as well as the ghostwriters of their encyclicals) had inherited. Decisively, they could only imagine the church intervening in secular affairs from its moral position on high, in ways that are intended to be constructive but remain limited to a model that smacked of noblesse oblige; they could not truly imagine the church engaging with secular social forces on terms the church would no longer control, and as just one of many coequal agents. It was only at the Second Vatican Council that we truly witnessed a shift from a model of "the teaching church" (ecclesia docens) to a more adequate and mixed model that made room for "the listening church" (ecclesia discens), at least in the officially recognized formulations of the church's self-understanding. Until Vatican II, then, the church's social teaching was still very much a monological, rather than a truly dialogical, process. Put another way, there could be excellent Catholic social teaching, but there was not yet a consistent and sustained commitment to Catholic social learning (Bergman 2011).

This crucial distinction, with broad implications for the influence and effectiveness of church social teachings, explains the title of the section of this present article: I would submit that the church's self-understanding of its role in society is governed either by a model of intervention or one of engagement. The theological about-face witnessed at the Second Vatican Council, whether we judge it to have occurred with genuine enthusiasm or, alternatively, primarily by necessity (and even perhaps with a whiff of continuing nostalgic longing for a medieval order in which the church enjoyed so many privileges and prerogatives) ushered in a transition from the "intervention model" to the "engagement 
model", as the operative understanding of the church-world relationship shifted in rapid order. The very texts of the social teaching documents before and after Vatican II provide a measure of this sea change. For their part, and by way of contrast, the postconciliar social teaching documents gradually widened their lens to read and interpret ever more of "the signs of the times", allowing the inherited deductive natural law framework to be gradually eclipsed by inductive social analysis of rapidly unfolding world events and new social movements. The text of the 1967 social encyclical of Paul VI is perhaps the most dramatic case in point; Populorum Progressio (Paul VI 2010b) deals with the urgent need for a new international economic order in the wake of rapid decolonization in a way that breaks new ground for its evident eager attentiveness to hearing the cry of the poor and engaging in a brand of social analysis that is modest and humble. Arguably, then, every papal social encyclical since Vatican II has reflected this shift in both method and tone, although commentators such as Mary Elsbernd have detected occasional papal backsliding on certain occasions, such as when John Paul II retreats from the previous progressive and inductive methodological commitments in his social teaching documents (Elsbernd 1995).

A final fruit of this review of developments in church history with relevance to Catholic social teaching is an enhanced appreciation of new potentialities for broad social partnerships in the post-Vatican II era. The new methodology and new tone of Catholic social teaching gradually fostered the dawning of new possibilities for collaboration for social justice. An organization (of any sort) which can only intervene (according to the older model as presented above) but not truly engage outside entities in an open and inclusive way is not a very promising candidate to be a responsive partner in bilateral relationships and multilateral coalitions for social change. The new attitude opened doors that had previously been closed, and arguably necessitated the closing of certain other doors. Theologian and missionary priest Donal Dorr identifies the latter half of the 1960s as the pivotal time in "the process by which the Catholic Church got new allies and new opponents". Dorr is quick to identify "Latin America [as] the region where the most dramatic changes took place", emphasizing decisions taken "by key leaders in the Church" to end its close affiliation with elites and dominant classes in favor of effecting "a preferential, but not exclusive, option for the poor" (Dorr 2016, p. 101).

Changes in the form and content of the church's social engagements certainly extended to other continents, as the pursuit of social justice could now induce Catholic efforts to effect positive social change through broad coalitions that now might include nontraditional allies of the church, such as socialist-leaning parties in Europe and elsewhere. In the United States, Catholic clergy and other leaders in this era experienced enhanced impetus to support civil rights and the antiwar movement, even when the politics of these social justice involvements made for some strange bedfellows and necessitated quite a bit of nose-holding on sensitive issues such as abortion policy and population control measures (where Catholic individuals and agencies were often at odds with otherwise desirable coalition partners, whose positions were at odds with the church). This opening up of new partnerships and alliances for Catholic institutions, leaders and laity after Vatican II is a premier example of the real-world implications of shifts in theological commitments and approaches.

\section{A Blueprint or a Yardstick?}

How may we characterize the legitimate role of Catholic social teaching in the mission of the Church? What analogies best capture the self-understanding of church leaders as they produce and promulgate documents that become key vehicles of that social teaching? We have already considered in broad strokes the transition in the course of the twentieth century to more modest stances and realistic assessments on the part of church leaders regarding the church's proper role in a pluralistic society, including its adoption of a model more accurately characterized as engagement than as intervention. Now we turn to the more specific matter of describing and portraying the optimal functioning of those social 
teachings. Our task is greatly facilitated by the explicit attention that is paid to this very matter in the texts of several of the teaching documents themselves.

Once again, Gaudium et Spes is a particularly helpful place to start. Number 76 of that Vatican II document contains eight short paragraphs under the heading "Politics and the Church" that constitute an explicit effort on the part of the Council Fathers to prevent any misconstrual of the overall document or, more broadly, of the overall project of Catholic social teaching itself. Like so much of Catholic theology, these paragraphs feature a "both-and", or "on the one hand... but on the other hand" quality to them. The second of these eight paragraphs reflects the agenda treated above, namely to explain and clarify the newfound stance of modesty on the part of the church as it approaches questions of social order. By no means does she intend to usurp the proper role of other institutions (e.g., courts, political parties, legislative bodies) that operate with legitimacy in their own spheres. The document here affirms: “The role and competence of the Church being what it is, she must in no way be confused with the political community, nor bound to any political system" (no. 76, par. 2).

This latter sentiment closely matches a core insight offered by John Courtney Murray (1960), the American Jesuit who served as a peritus at the final sessions of the Second Vatican Council. Widely considered the premier Catholic architect of public theology in our age, Murray insisted on the drawing of careful distinctions relating to the proper roles of political and religious communities-that is, close attention to the specific duties of church and state. If an overly ambitious agenda is to be avoided by church authorities, it would also be imprudent to err on the opposite side of this balance. While the church is eager to disavow any efforts to engage in bullying in the political order, it must also be wary of acting so timidly that its distinctive voice ceases to be heard in the corridors of power, especially when it has something valuable to offer (perhaps by way of ethical advice or reminders of moral obligations) in the political sphere. That venerable phrase "exercising the freedom of the church", forged in more contentious times of church-state conflict featuring fierce contests for dominance on the part of assertive popes (recall Boniface VIII) and powerful emperors, captures well some of the core concerns even in this age of more subtle challenges, when efforts to advance the concern for justice found in the Gospel are more likely than the thirst for social hegemony to motivate church actions. The church's social mission includes advocacy for both the temporal and spiritual flourishing of all, thus: "[The church] has the right to pass moral judgments, even on matters touching the political order, whenever basic personal rights or the salvation of souls makes such judgments necessary" (no. 76, par. 7). Without such forthright assertions of its right to speak out against injustice and disorder, Catholic voices in various parts of the world would not have been sufficiently emboldened to challenge predatory economic systems (during this era of both decolonization and neo-imperialism) or corrupt political establishments (such as those that held sway behind the Iron Curtain, including in Poland where the future John Paul II, a member of the drafting committee of Gaudium et Spes, was at the time a young bishop).

It was indeed to John Paul II, a decade after his election as pope and over two decades after the close of Vatican II, that an opportunity arose to clarify the church's stance regarding its mission to serve as an outspoken critic of injustices. In the last social encyclical of the Cold War era, Sollicitudo Rei Socialis, published late in 1987, the Polish pontiff inserted the most detailed explanation yet offered in any teaching document for the aspirations, rationale and proper boundaries of Catholic social teaching. The distinctions he introduces justify quoting number 41 of that encyclical at some length:

"The Church does not have technical solutions to offer ... For the Church does not propose economic and political systems or programs, nor does she show preference for one or the other, provided that human dignity is properly respected and promoted ... But the Church is an expert in humanity, and this leads her necessarily to extend her religious mission to the various fields in which men and women expend their efforts in search of the always relative happiness which is possible in this world, in line with their dignity as persons ... Whatever affects 
the dignity of individuals and peoples, such as authentic development, cannot be reduced to a "technical problem" ... This is why the Church has something to say today about the nature, condition, requirements, and aims of authentic development, and also about the obstacles which stand in its way. In doing so the Church fulfills her mission to evangelize ... The Church's social doctrine is not a "third way" between liberal capitalism and Marxist collectivism, nor even a possible alternative to other solutions less radically opposed to one another; rather, it constitutes a category of its own. Nor is it an ideology ... but belongs to the field ... of moral theology." (John Paul II [1987] 2010)

Of perhaps the greatest importance for present purposes is the distinction introduced here between technical and moral aspects of temporal affairs. Despite having at their disposal the substantial resources of such advisory bodies as the Pontifical Academy of Social Science, popes have never used their teaching documents to weigh in at any significant level of detail on disputed matters of public policy. Though maddening to anyone expecting straightforward policy solutions, social encyclicals display great care in presenting moral argumentation drawn from sources revered within church tradition without specifying detailed applications of the principles presented. The project of Catholic social teaching has never represented an opportunity for church leaders to score political points or endorse a given ideology wholesale, as John Paul hastened to clarify here.

Rather than setting itself up as a provider of policy advice or even as a ranker of preferences, in its social teachings, the church aspires only to play the role of a moral teacher. The texts of social encyclicals typically devote a great deal of space to extoling and commending the central virtues (e.g., generosity and solidarity) that relate to harmonious social order, both on the part of individuals and collectivities, without so often descending into specifics. Hence, the church's teaching responds to challenges of the time in such a way as to provide only general ethical guidance to believers as they seek to inform their own consciences on economic and political matters proper to their lives. This is why John Paul II was so fond of repeating that the church only proposes ethical values, never imposes preferred solutions to social problems. Putting aside the somewhat time-bound references in the citation above to the ideological and superpower rivalry that unfolded in the course of the Cold War, it is clear that Catholic social teaching displays no appetite for playing favorites or taking sides vis à vis existing ideologies, nor an inclination to split the difference between rival political or economic systems, but only to fulfill the eminently pastoral and teaching functions that constitute its social mission. The core aspiration of Catholic social teaching is to contribute to the dignity and flourishing of individuals and societies in light of the Christian Gospel.

The foregoing analysis allows us more easily to take up the task suggested by the title of this section. To expect Catholic social teaching to provide anything that resembles a blueprint for social order would entail asking it to exceed its mission, if not to betray its calling entirely. It functions as a value-raiser, not an answer-giver. While Catholic teachings insist on such values as the protection of human dignity and the promotion of the common good, they seek not to direct or control the process by which a given society pursues those goods, but rather to assist those who are discerning the way forward. If it cannot be likened to a blueprint, then, perhaps the more modest analogy of a yardstick fits the proper functions of Catholic social teaching very well, capturing its purpose of assisting in the task of measuring the attainment of social justice. While blueprints drawn up by architects direct the work of builders in a comprehensive way, yardsticks provide the more modest service of helping builders measure the component pieces of a larger project, subjecting them to a calibrated test according to standard measures that have stood the test of time. Yardsticks are useful tools because they provide criteria for judgment; social systems and economic policies are subjects of profitable measurement every bit as much as wooden planks or iron girders. Interestingly, the yardstick analogy was employed to especially good effect (if not originally pioneered) by Msgr. George G. Higgins (1916-2002), a prominent labor priest and longtime director of the Social Action Office of the U.S. Bishops' Conference. His 
regular column on Catholic social thought, syndicated nationwide in diocesan newspapers for four decades, was titled "The Yardstick".

Simply acknowledging the aptness of the yardstick analogy by no means completes the work of Catholic social teaching. Whatever judgments are to be made (and the next section addresses questions regarding the appropriate levels of church and society for these tasks), there is still much empirical work to be done before we can reach reliable judgments regarding which courses of action will indeed fulfill the criteria and advance the values delineated by Catholic social teaching. Does a given institution or policy in fact deliver on its promise of promoting human flourishing or the common good? Are there unanticipated consequences that might affect the magnitude or the distribution of burdens and benefits that thereby render an initially attractive proposal ineffective or entirely unworkable? As is captured by the idiomatic expression "the devil is in the details", complications quickly arise when we descend from the level of pure ideals and general aspirations to the level of nuts-and-bolts implementation.

\section{Universal Principles or Local Applications?}

In contrast to the appearance of the paired terms mentioned in the titles of the previous two sections, the title of this section invites us to synthesize two options rather than to fully embrace one and utterly reject the other item mentioned. In keeping with a prevailing inclination within Catholic theology, this section will display a "both-and" orientation that dismisses neither term in the section title, but rather endorses a prudently drawn relationship between universal principles proposed by Catholic social teaching and sensitive local applications of these same principles. The church's mission to foster social justice advances when this delicate balance is struck so that neither level is neglected.

Seeking to clarify these very points, Pope Paul VI, in number 4 of his 1971 Apostolic Letter Octogesima Adveniens ("A Call to Action on the Eightieth Anniversary of Rerum Novarum"), offered this clarification regarding the relationship between universal principles and local applications:

"In the face of such widely varying situations, it is difficult for us to utter a unified message and to put forward a solution which has universal validity. Such is not our ambition, nor is it our mission. It is up to the Christian communities to analyze with objectivity the situation which is proper to their own country, to shed on it the light of the Gospel's unalterable words and to draw principles of reflection, norms of judgment and directives for action from the social teaching of the Church." (Paul VI [1971] 2010a)

Before analyzing this passage, a few ecclesiological clarifications are in order. In church parlance, "Christian communities" (in the plural) is a term referring to local or regional church groupings, such as parishes (headed by a pastor), dioceses (headed by a bishop) and (with increasing relevance in recent decades) national episcopal conferences such as the United States Conference of Catholic Bishops (USCCB). This organization is the collection of over 200 Catholic bishops who (alongside many other specifically internal church functions) frequently deliberate on matters of social justice and public policy at the national level. Their plenary meetings usually occur twice per year, and they maintain a large professional staff headquartered in Washington, D.C., including offices treating matters of social justice and public policy (most prominently, its Department of Justice, Peace and Human Development). There are over one hundred of these Catholic entities throughout the world, and naturally, some bishops' conferences are more active than others in advocating for justice and peace (even engaging in activities such as lobbying legislators at state and national levels). Although episcopal conferences are somewhat peripheral to formal church governance (their functions are mentioned only a handful of times in the 1983 Revised Code of Canon Law, and bishops are juridically accountable ultimately to the pope alone, rather than to the leadership of the local episcopal conference), since their advent in the nineteenth century an increasing number of practical administrative church functions have fallen to them. 
As the pope who concluded the Second Vatican Council and led the church through substantial updating and reorganization based on the work of that momentous event, Paul had overseen the carving out of tasks that were newly delegated to these increasingly important episcopal conferences. For example, national or regional episcopal conferences (usually through appointed committees of member bishops and trusted expert advisors) were charged with adopting liturgical texts newly translated into the vernacular language of a region, and for overseeing revised curricula for seminary education. Such tasks, quite obviously internal to the life of the church, were matched in the post-Vatican II era with functions relating to the outward-looking gaze of the Catholic Church, including concerns for the advancement of social justice. Thus, the worldwide network of episcopal conferences came to be in their own right carriers of Catholic social teaching. They were understood not as independent agents that would operate without reference to the Vatican, but rather as communities of discernment capable of coordinating local efforts to advance justice with appropriate direction provided under papal auspices. In fact, Pope Paul had, just four years before issuing Octogesima Adveniens, established the Pontifical Council for Justice and Peace (since 2017, called the Dicastery for Promoting Integral Human Development) which serves as a central resource for local, national and regional efforts in the field of peace and social justice.

In light of the proceeding description of the ecclesial landscape, it is clear that much of what Pope Paul says in this citation boils down to sheer common sense, mixed with a dose of inherited theological wisdom. In line with the theological principle of subsidiarity, programmatic pastoral planning has no choice but to proceed at the grassroots level. It is both impractical and disrespectful for an authority figure (even a pope) in one part of the world to propose directions for action in the wide variety of local settings where they will have effect. Since church leaders have long appropriated this insight, a felicitous division of labor guides the diverse actions of church-based agencies to this day, allowing the church to take advantage of the most effective levels of analysis and social action. Indeed, if there is a recurring lesson to be highlighted, it is that the center of gravity for faith-based social initiatives tends to devolve (and rightly so) to the local level, where so much of the vitality of any faith community is located. Simply put, social ministries thrive at the grassroots.

Returning to the 1971 citation, Pope Paul rather deliberately uses the terms "unified message" and "universal validity" to indicate positions he is eager to disavow. It is certainly not the case that principles such as human dignity and duties to the common good are somehow suddenly of negotiable value or, in an increasingly complex world, have come to depend upon contingent local conditions. By no means is Paul VI making a concession to relativism of any sort. Rather, much like the ethical content of the Gospel itself, these Catholic social teaching principles of course retain their force but must be understood as requiring careful application to local circumstances, preferably through the agency of those with adequate knowledge of the circumstances in which they will be applied. Every corner of the world has its own distinctive cultures and its most urgent needs and challenges; it would constitute an act of hubris for an outsider to dictate precisely how principles apply to an unfamiliar local setting. The most prudent acts of diagnosis and prescription (to invoke a useful medical analogy) will come from those who know the patient best, and recommendations for action must be preceded by respectful encounter, not one-size-fits-all responses that invariably cut too many corners to be deemed responsible and likely effective.

Pope Paul VI concludes this paragraph by mentioning three items that have occasioned the spilling of much ink: "principles of reflection, norms of judgment and directives for action". What is the pope specifying by invoking this triad of terms? Presumably, each of these phrases refers to a distinct reality of some sort, although the text nowhere clarifies what Paul had in mind specifically. We may well speculate that he desired here to highlight the importance of engaging in those intermediate steps that must be traversed on the way to an adequate determination of a course of action in any discernment. While it remains unclear whether and how Paul intended to distinguish these three items and relate each to 
the others, we may perhaps draw from this sentence further lessons regarding respect for the "warp and woof" of life on local levels. Longtime administrator that he was, Paul was familiar with the shortcomings of pre-packaged (supposed) solutions to local problems, and seems to be pointing his audience toward the ongoing and inescapable imperative to take fully into consideration the key realities specific to any situation before pronouncing a plan of action-to advance social justice or to achieve worthy goals of any sort.

The popes who followed Paul VI continued to highlight similar lessons with great import for the understanding and application of Catholic social teaching. We have already glimpsed some of the most relevant words of John Paul II on these matters regarding how the church's social teachings are intended. Five years after issuing Sollicitudo Rei Socialis, he returned to the topic with an even greater sense of urgency, as he was eager to set the record straight in light of the frequent twisting of his words after the fall of the Berlin Wall. His September 1993 apostolic visit to Latvia, a former Soviet republic still enjoying its first months of post-Communist liberty as it fashioned its first foray into life within a market economy, occasioned a heartfelt plea by the Polish pontiff not to misunderstand the purpose of Catholic social teaching. In a brief but stunning address at the University of Latvia in the capital city of Riga, John Paul warned that nothing the church had ever said amounts to a wholesale vindication of free-market capitalism, or should ever be understood as an endorsement of any particular economic or political system. The text of his speech that day, titled "What Church Social Teaching Is and Is Not", recapitulates many of the lessons we have seen above: that "the political and economic spheres ... enjoy an intrinsic autonomy"; that "the church does not feel called to offer technical options ... [but that] the church's specific mission is spreading the Gospel and the formation of consciences" ... ; that "Catholic social doctrine has always distanced itself from capitalistic ideology... even after the historical failure of communism ... Its task is not to draw up a 'system' but to indicate the impassible limits and suggest possible ways so that the various political and economic policies formulated in the concrete history of peoples in relationship to an infinite number of variables may be worthy of humankind and in conformity to the moral law" (John Paul II 1993, p. 257).

While Pope Francis for his part has not addressed these matters regarding the status of Catholic social teaching in as much detail as his Polish predecessor, he has done us the great service of offering his own distinctive guidance on discerning the shape and scope of our social obligations. Somewhat typical for the Jesuit pope, this contribution turns out to pivot upon certain well-chosen rhetorical tropes as much as upon analytic categories. In advance of the 2021 World Day of Peace, Francis released the annual papal message marking this occasion (1 January 2021). In the course of this brief document, the Argentinian pope leaned on a favorite trope employed frequently in his papacy: analyzing global developments and realities in terms of categories labeled as "the culture of ... [insert object]". In the first eight years of his papacy, he had relied upon this phrasing pattern to praise a number of key human responses, describing them as indicative of laudable Christian attitudes and actions. Thus, we hear Francis speak frequently of the culture of encounter, accompaniment, inclusion, solidarity and mercy, to cite the five most frequent (by my own unscientific count) positive items. On the negative side, he has warned most frequently against the culture of indifference, exclusion, inequality, and "throwaway" - themes sharply at odds with the Gospel message.

Here, in the context of a message on the importance of fostering peace, Francis chooses to highlight a phrase that had not been so prominent previously in his rhetoric: "a culture of care". Indeed, the very title he selected for the document is "A Culture of Care as a Path to Peace". Francis devotes several consecutive paragraphs in the middle of the document to spelling out the shape of a culture of care, and links it closely with several key themes of Catholic social teaching, even spending a full quarter of the document enumerating and explaining four of these familiar themes, which he casts as aspects of the culture of care. However, even more significantly for present purposes, Francis introduces an original 
analogy to capture the guidance that Catholic social teaching provides to those who exert efforts to establish the culture of care: a moral compass.

It is in the final third of this document (i.e., numbers 7 to 9) that Francis takes up this creative analogy and runs with it in interesting directions. He introduces the analogy in the context of a rare first-person appeal to prominent people worldwide to appropriate the lessons of Catholic social teaching. He pleads: "I urge government leaders and those of international organizations, business leaders, scientists, communicators and educators, to take up these principles as a 'compass' capable of pointing out a common direction and insuring a more human future .... I ask everyone to take this compass in hand and to become a prophetic witness of the culture of care ... " (Francis 2021). After presenting a litany of virtues (including fraternity, mutual respect, and sensitivity to human rights and humanitarian law), Francis returns to the metaphor, asserting that "the compass of these social principles" holds great promise in tasks related to peace (disarmament, conflict resolution, and the establishment of security), both within and between nations.

After invoking the compass metaphor again to introduce a panorama of contexts (family, the educational sector, even religious communities themselves) where "a culture of care" is urgently required, Francis closes the document in a particularly deft way. While many papal documents close with somewhat generic homiletic appeals to Marian piety, here Francis continues this tradition by applying the compass metaphor to especially good effect. The final paragraph of the document makes reference to the traditional title of the Blessed Virgin Mary as "the Star of the Sea" (on account of her repeated intercessions on behalf of sailors, who incidentally are in the best position of anyone to make good use of a literal compass). The nautical metaphor is extended with references to "the barque of humanity, tossed by the storm of the current [pandemic] crisis" and "the rudder of human dignity" which can assist us in our "struggles to advance toward a calmer and more serene horizon". However, all these stylistic embellishments do not distract from the central metaphor Francis offers (in the penultimate sentence of the document) of "the compass of fundamental principles [that] can enable us together to steer a sure course" (Francis 2021).

I parse this document so closely not so much to call attention to the rhetorical originality of Pope Francis, but to highlight the analogy of the moral compass that he introduces here. To the previously mentioned analogies of blueprint (which is ultimately not true to the church's intentions) and yardstick (which is useful but somewhat cramped for present purposes), Catholic social teaching now enjoys a more imaginative analogy—one that is not only accurate but potentially inspiring. The church's social teaching does indeed provide a moral compass-a reliable instrument of navigation that allows the user to orient oneself and even to project future directions. If the Catholic community is to reach well-considered judgments regarding existing efforts to advance social justice or to endeavor to launch initiatives of its own, then the church's social teachings will surely be an indispensable tool in these projects.

\section{Concluding Reflections}

Although the analysis offered above is wide-ranging-drawing as it does upon church history, theology and the texts of many church documents - the take-aways regarding the use and potential misuse of Catholic social teaching are not so difficult to summarize. Many of the specifically theological insights most relevant to this Special Issue of the journal Religions may be captured in a few pithy guidelines, some of which contain admonitions that may be expressed in the form of appealing and memorable sound bites. Catholic social teaching is intended as a conversation-starter, rather than as a conversation-stopper. Through it, the church seeks to propose, never to impose, prescriptions for the attainment of social justice. It consists neither of vague truisms and nebulous generalizations nor of highly detailed directives for public policy, as it charts a course of constructive engagement in public life-one that always remains above the fray of narrowly partisan politics or ideological allegiances. At their best, the many Catholic contributions to social justice efforts respect key distinctions governing religious conviction and moral conscience in our situation of great pluralism, not to mention the institutional distinction between church 
and state. Attending carefully to this array of distinctions in a consistent way renders the church a more constructive partner in dialogue and social action in broad coalitions for social change and institutional reform.

This list of summary guidelines and characterizations could be multiplied at great length, but underlying all this practical wisdom for the appropriate employ of Catholic social teaching is an awareness of the age-old distinction, reaffirmed time and again within the documents and agents of the church's social teaching: the distinction between a condition and a problem. Surveying the landscape of life in contemporary society, replete as it is with a tragic abundance of human suffering, observers might be tempted simply to shrug their shoulders and pronounce the regrettable damage meted out to victims of grave economic injustices as a mere condition-something that might be desirable to rectify but ultimately is to be tolerated. This fatalistic attitude has never been reconcilable with Catholic social teaching. Starting in 1891 with Pope Leo XIII's cry of protest against the dehumanizing circumstances faced by the working poor of his day (he referred to it in the second paragraph of Rerum Novarum as "a yoke little better than slavery itself") and extending to the repeated pleas for economic reform issued by Pope Francis in his social encyclicals and many heartfelt addresses on this topic, dire poverty emerges as a phenomenon that is more than a mere condition for the Catholic community. Avoidable human suffering is fully and undoubtedly a problem-something intolerable that demands our attention and lays claim to all our energies to correct, reverse and overcome such disorder.

The moral demands imposed upon us by the persistence of social injustices have moved not just leaders but all members of the church to mobilize resources and undertake immense private charitable efforts to offer direct material assistance; alternately, it has inspired them to support ambitious public measures that more systematically address the root causes of these social ills. The "corporal works of mercy" performed by the wide variety of church projects (such as those under the auspices of Catholic Charities and the worldwide network of Saint Vincent de Paul Societies) may appear very different from Catholic Church advocacy for welfare state programs delivering income support and in-kind assistance to low-income families, but they proceed from the same core motivation, which arises in the text of Gospel itself. Indeed, we need look no farther than the Parable of the Good Samaritan, which maintains its place as a "Christian classic" and paradigmatic foundation for broad social concern in the church's tradition. The vivid story of the Samaritan's kindness to the victimized stranger-appearing in chapter 10 of Luke's Gospel-is still so poignant and relevant to our world of widespread indifference to suffering that Pope Francis explicated this episode's emblematic features in a full chapter of his social encyclical Fratelli Tutti (Francis 2020).

The Good Samaritan narrative (which ends with Jesus's admonition: "Then go and do likewise", in Luke 10:37) addresses the pivotal questions of what it means to be a true neighbor to those in need of assistance. As such, long before the distinctive notes of urgency struck by Pope Francis in citing this parable, it has inspired the Catholic response to human suffering in its many faces; it has shaped the consciences of millions throughout the church's long history and has motivated both the voluntary outreach we call charity and the more systematic efforts to advance social justice. Even when those efforts in the struggle for better outcomes seem quite indirect-when they include calls to muster resources for social empowerment administered through public agencies-they retain their connection to the Gospel-inspired sense of social obligation, which includes not only binding up the wounds of victims but also preventing victimhood in the first place. Love of neighbor surely includes advocating for a more humane economy, overturning structures of oppression, and challenging a status quo that tolerates the exclusion of many from economic opportunities. In theological language, such initiatives constitute "faith active in love", which is the mark of Christian social responsibility. Faith convictions have social implications, some of which play out even on the grand stage of national and global politics. When Catholic voices advocate for more generous social policies, especially in response to relentless recent efforts to denigrate or delegitimize the welfare state, they are practicing 
what they understand to be "a faith seeking justice", which sometimes necessitates a measure of prophetic denunciation of injustices in the service of "a bold politics of love".

As a church that possesses a robust public theology (one that features an unapologetic embrace of social responsibility), Catholicism retains its commitment to offer moral guidance for public policy-always along lines that feature prudent restraint, respect for pluralism, and the additional caveats described above. As a "community of memory" that has been grappling with issues of proper social order for two millennia now, the Catholic Church has exerted (in the first instance) a formational influence upon its members that encourages them to perceive dire poverty and preventable human suffering truly as problems that urgently cry out for solution, not merely as conditions to be tolerated. However, the aspiration opens out (in a second instance) from there: it is of course true that none of these problems can be addressed without broad-based coalitions for social change, nor in the absence of the detailed analysis invited by this consequential Special Issue of this journal and conducted by the contributing authors.

Pointed and fascinating questions immediately arise: How well has Catholic social teaching functioned as a builder of bridges to wider communities of people of conscience? How effective have various social action projects based in the Catholic Church been in fostering policy change and structural reform in various local and national contexts? How often and under what conditions has the faith-based advocacy launched in Catholic circles succeeded in its purpose? What factors are correlated with the greatest instances of effectiveness for these initiatives? These are the practical aspects regarding the influence of Catholic social thought that merit our attention and constitute a research agenda of great importance.

Funding: This research received no external funding.

Institutional Review Board Statement: Not Applicable.

Informed Consent Statement: Not Applicable.

Data Availability Statement: Not Applicable.

Conflicts of Interest: The author declares no conflict of interest.

\section{Notes}

1 (Second Vatican Council 1966a).

2 (Second Vatican Council 1966b).

3 On this topic, on 18 November 1965, the Second Vatican Council approved its landmark "Decree on the Apostolate of the Laity" (Apostolicam Actuositatem), the full text of which appears in Abbott, ed, pp. 489-521.

4 The texts of the papl encyclicals mentioned in this paragraph, as well as several documents mentioned below in this essay, appear in (O’Brien and Shannon 2010).

\section{References}

Abbott, S.J., Walter M., ed. 1966. The Documents of Vatican II. New York: The America Press.

Bergman, Roger. 2011. Catholic Social Learning: Educating the Faith That Does Justice. New York: Fordham University Press.

Bruce, Steve. 2011. Secularization: In Defense of an Unfashionable Theory. New York: Oxford University Press.

Dorr, Donal. 2016. Option for the Poor and for the Earth: From Leo XIII to Pope Francis: Revised Edition. Maryknoll: Orbis Books.

Dulles, Avery. 1978. Models of the Church. Garden City: Image Books of Doubleday and Company.

Elsbernd, Mary. 1995. Whatever Happened to Octogesima adveniens? Theological Studies 56: 39-60. [CrossRef]

Francis, Pope. 2020. Fratelli Tutti: Encyclical Letter on Fraternity and Social Friendship. Published 3 October 2020. Available online: http:/ / www.vatican.va/content/francesco/en/encyclicals/documents/papa-francesco_20201003_enciclica-fratellitutti.html (accessed on 28 February 2021).

Francis, Pope. 2021. Message for the 54th World Day of Peace, "A Culture of Care as a Path to Peace". 1 January 2021. Available online: http:/ / www.vatican.va/content/francesco/en/messages/peace/documents/papa-francesco_20201208_messaggio-54 giornatamondiale-pace2021.html (accessed on 28 February 2021).

Leo XIII, Pope. 2010. Rerum Novarum: Encyclical Letter on the Condition of Labor. In Catholic Social Thought: The Documentary Heritage, Expanded Edition. First published 1891. Edited by David J. O’Brien and Thomas A. Shannon. Maryknoll: Orbis Books, pp. 14-40.

Murray, John Courtney. 1960. We Hold These Truths: Catholic Reflections on the American Proposition. New York: Sheed and Ward. 
Niebuhr, H. Richard. 1951. Christ and Culture. New York: Harper \& Row Publishers.

O'Malley, John W. 2008. What Happened at Vatican II. Cambridge: Harvard University Press, pp. 53-92.

John Paul II, Pope. 1993. What Church Social Teaching Is and Is Not: Address at the University of Latvia in Riga, 9 September 1993. Origins 23: 256-58.

John Paul II, Pope. 2010. Sollicitudo Rei Socialis: Encyclical Letter on Social Concern. In Catholic Social Thought: The Documentary Heritage, Expanded Edition. First published 1987. Edited by David J. O’Brien and Thomas A. Shannon. Maryknoll: Orbis Books, pp. 424-68.

O'Brien, David J., and Thomas A. Shannon, eds. 2010. Catholic Social Thought: The Documentary Heritage, Expanded ed.. Maryknoll: Orbis Books.

Paul VI, Pope. 2010a. Apostolic Letter Octogesima Adveniens: A Call to Action on the Eightieth Anniversary of Rerum Novarum. In Catholic Social Thought: The Documentary Heritage, Expanded Edition. First published 1971. Edited by David J. O'Brien and Thomas A. Shannon. Maryknoll: Orbis Books, pp. 280-303.

Paul VI, Pope. 2010b. Populorum Progressio: Encyclical Letter on the Development of Peoples. In Catholic Social Thought: The Documentary Heritage. Expanded ed. Published 26 March 1967. Edited by David J. O'Brien and Thomas A. Shannon. Maryknoll: Orbis Books, pp. 253-77.

Second Vatican Council. 1966a. Dignitatis Humanae: Declaration on Religious Freedom. In The Documents of Vatican II. Approved 7 December 1965. Edited by Walter M. and S. J. Abbott. New York: The America Press, pp. 675-96.

Second Vatican Council. 1966b. Gaudium et Spes: Pastoral Constitution of the Church in the Modern World. In The Documents of Vatican II. Approved 7 December 1965. Edited by Walter M. and S. J. Abbott. New York: The America Press, pp. 199-308.

Tierney, Brian. 1988. Unam Sanctam of Pope Boniface VIII: Text and commentary. In his The Crisis of Church and State 1050-1300. Toronto: University of Toronto Press, pp. 180-89.

Tracy, David. 2020. Religion in the Public Realm: Three Forms of Publicness. In His Fragments: The Existential Situation of Our Time: Selected Essays. Chicago: University of Chicago Press, vol. 1, pp. 271-90.

Weber, Max. 1946. The Social Psychology of the World Religions. In From Max Weber: Essays in Sociology. Edited by Hans Heinrich Gerth and C. Wright Mills. New York: Oxford University Press, pp. 267-301. 